\title{
X-ray Diffraction and Fourier Transform Study of Toxic Effect of Heavy Metals on Bone Tissues of an Edible Fish Cirrhinus mrigala
}

\author{
S. KARTHIKEYAN* \\ Department of Physics, St. Joseph's College of Engineering, Chennai-600119, Tamil Nadu, India
}

(Received November 16, 2011)

\begin{abstract}
Toxic effect of heavy metals due to nickel and chromium on bone tissues edible fish Cirrhinus mrigala was studied using spectroscopic techniques. The study shows that there is significant change in the bone minerals contents and it is more pronounced in nickel than chromium.
\end{abstract}

PACS: 87.64.K-, 87.64.- $-\mathrm{t}$

\section{Introduction}

Pollution of the marine ecosystem by toxic metals like nickel, chromium, cadmium, mercury, lead, etc., is widespread. Metals after entering the water may precipitate or adsorb on the surface of solids, remain soluble or suspended in it or may be taken up by fauna and flora. Numerous studies have been carried out to assess freshwater pollution by the discharge of effluents from industries [1,2]. The accumulation of heavy metals in water suggests that fish may serve as a useful indicator for contaminating metals in aquatic systems. Since fishes are often the last link in the aquatic food chain, the metal concentration of many fish species has been analyzed in relation to the metal content of aquatic environment [3].

Bone is formed by the infusion of an organic matrix, principally of collagen, and with calcium phosphate and it gives rigidity so that the tissue can fulfill its supportive and protective functions and provide movement. Secondly, bone minerals are in metabolic interrelation with body fluids, serving principally as a reservoir for many of the ionic constituents of the body mineral [4], storing or releasing them as need arises. It is known that there is a close relationship between the low $\mathrm{Ca}: \mathrm{PO}_{4}$ ratio and the corresponding increase in apparent $\mathrm{HPO}_{4}$ content, the high content of tightly bound water, and the low degree of crystallinity. Diseased/immature bone is thought to contain more $\mathrm{ACP}$, having low $\mathrm{Ca}: \mathrm{PO}_{4}$ ratio and a low degree of crystallinity than the mature bone. Hence the determination of the exact chemical composition and crystallographic structure of the bone mineral play an important role.

\footnotetext{
* e-mail: physicskarthik@gmail.com
}

Bioconcentration of chemicals in aquatic biota is an important factor in the assessment of the potential hazard of chemicals to the environment [5]. Many researches are done on toxicity of heavy metals $[6,7]$ on bioaccumulation, its effects of protein contents [8] due to these heavy metals and the influence of $\mathrm{pH}$ and water hardness [9]. But only few researches are done on toxicity of heavy metals on bone tissues of an edible fish. Hence keeping in view of this the present study aims at toxicity study of heavy metals nickel and chromium on bone tissues of edible fish Cirrhinus mrigala.

\section{Materials and methods}

\subsection{Experimental methods}

The experiments were carried out at $(28 \pm 1)^{\circ} \mathrm{C}$ in an aerated plastic trough. Freshly collected animals (Cirrhinus mrigala) of length $6 \pm 2 \mathrm{~cm}$ weighing approximately $10 \mathrm{~g}$ were collected from local pond. They were acclimatized in the laboratory conditions for a period of seven days. Then they were divided into three groups. Group 1 , consisting twenty animals, were placed in a plastic trough $45 \times 32 \times 25 \mathrm{~cm}^{3}$ and kept in clean water. The group 2 and group 3 fishes were exposed to $1 / 3$ rd of lethal concentration 50\% (LC50) $3.61 \mathrm{ppm}$ and $6.06 \mathrm{ppm}$ concentrations of nickel and chromium, respectively. The test fishes were exposed to above-mentioned sub-lethal concentrations separately for a period of four weeks. To study the excretion process, the groups of fishes at the end of those periods were randomly selected from the experimental tank and kept in clean water (elimination period) for another period of four weeks which is treated as group 4 and 5 . At the end of the exposure period bone tissues were isolated and kept in a freezer $\left(-20^{\circ} \mathrm{C}\right)$ prior to analysis. 


\section{2. $X R D$ analysis}

The X-ray diffraction analysis was performed on a JEOL-JDX 8030 powder diffractometer with the use of $\mathrm{Cu} K_{\alpha}$ radiation at a step of $1 / 2^{\circ}$ degree and a time/ step of $2 \mathrm{~s}$. JCPDS file were used for peak identification. The angle of diffraction was $2 \theta=3^{\circ} \div 65^{\circ}$. In the present study, the bone tissue samples were exposed to higher sub-lethal concentrations of $\mathrm{Ni}$ and $\mathrm{Cr}$ and the respective recovery was used for the analysis. At the end of the experimental period, the fishes were scarified and their bone tissues were carefully removed from the surrounding soft tissue placed in a freezer-drier and then in Edwards's vacuum freeze drier. The samples were made into fine powder using agate mortar to an approximate particle size of 600 and stored in a dissector until use.

\subsection{FTIR analysis}

The samples were lyophilized and made into fine powder. The bone tissue powder samples and $\mathrm{KBr}$ (all solid dry state) were again lyophilized in order to remove most bound water which might interfere with the measurement of the amide I band. Approximately $5 \mathrm{mg}$ of the sample is mixed with $100 \mathrm{mg}$ of dried $\mathrm{KBr}$ and then pressed into a clear pellet of $13 \mathrm{~mm}$ diameter and $1 \mathrm{~mm}$ thickness. Absorbance spectra were recorded using Nicolet Avatar-360 FTIR spectrometer equipped with a $\mathrm{KBr}$ beam splitter and a DTGS detector installed at the Centralised Instrumentation and Services Laboratory, Annamalai University. For each spectrum 100 scans were co-added, at a spectral resolution of $4 \mathrm{~cm}^{-1}$. The spectrometer was continuously purged with dry nitrogen. The absorption intensity of the peak was calculated using the base line method. Each observation was confirmed by taking at least three replicates.

\subsection{Estimation of $\mathrm{Ni}, \mathrm{Cr}, \mathrm{Ca}, \mathrm{Mg}$, and $\mathrm{P}$}

Bone tissue samples were digested with concentrated nitric acid and perchloric acid by standard digestion method [10]. The concentration of $\mathrm{Ni}, \mathrm{Cr}, \mathrm{Ca}, \mathrm{Mg}$ and $\mathrm{P}$ present in the bone tissues were estimated by inductively coupled plasma atomic emission spectrometer (ICP-AES) available in the CAS in marine biology, Annamalai University.

\section{Results and discussion}

\section{$3.1 X R D$ and ICP-AES analysis}

Figure 1 shows the representative $\mathrm{X}$-ray diffraction pattern obtained for control, nickel and chromium treated bone tissues of Cirrhinus mrigala along with respective recovery. As could be seen from the diffractogram, the overall peak intensity decreased in metal treated tissues when compared to the control. Also, from the diffractogram, minerals like amorphous calcium phosphate (ACP), calcium magnesium phosphate (CMP) and calcium carbonate are identified using JCPDS files, and the observed $2 \theta, d$, and $I$ values are presented in Table I.

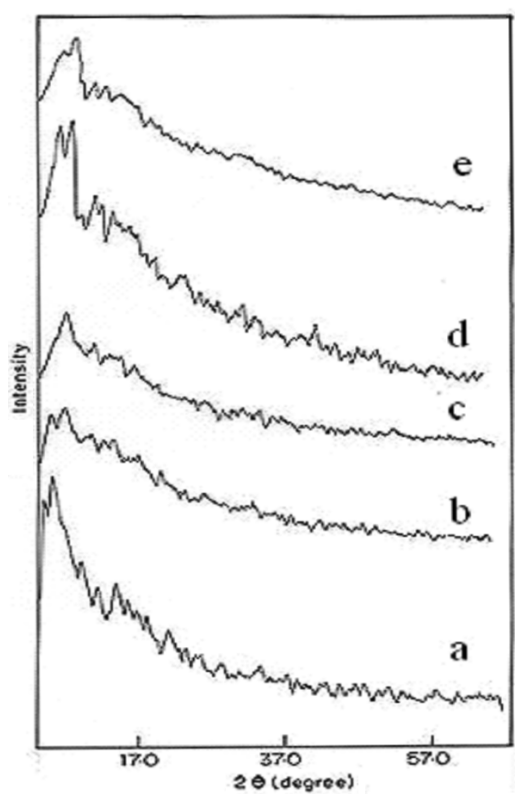

Fig. 1. X-ray diffractogram of bone tissue of Cirrhinus mrigala: $a$ - control, $b$ - nickel treated, $c$ - chromium treated, $d-$ nickel recovery, $e-$ chromium recovery.

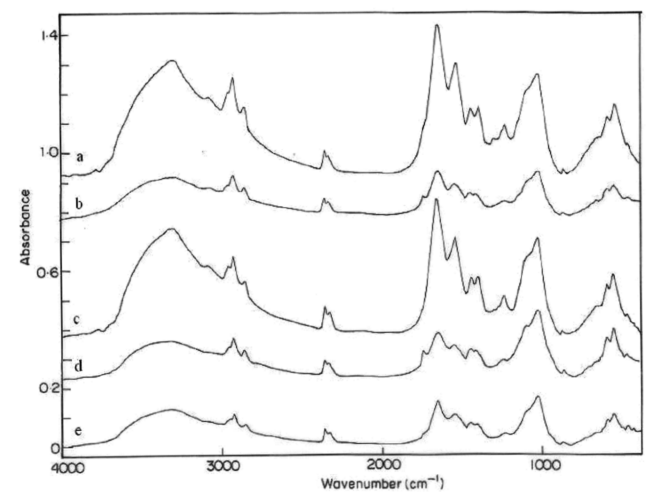

Fig. 2. FTIR spectra of bone tissues of Cirrhinus mrigala: $a$ - control, $b$ - nickel treated, $c-$ chromium treated, $d-$ nickel recovery, $e-$ chromium recovery.

Turan et al. [4] have suggested that the intensity variation of the peak in XRD pattern reflects the change in mineral content between the control and the selenium treated rat bone. The observed changes in intensity of the peaks in both treatment and recovery may be attributed to changes in the mineral content. The XRD spectra obtained in the present study reveals that bone tissue is of amorphous nature and the intensity of the mineral content in metal ( $\mathrm{Ni}$ and $\mathrm{Cr}$ ) treated bone tissues is less when compared to that of control. It could also be observed that this decrease of peaks intensity is more pronounced in nickel than in chromium. To support the X-ray diffraction (XRD) analysis, ICP-AES results and the Fourier transform infrared (FTIR) studies were also made. 
Comparison of XRD intensities in the treated and recovery bone tissue of Cirrhinus mrigala.

TABLE I

\begin{tabular}{c|c|c|c|c|c|c|c|c|c|c|c|c|c|c}
\hline \hline \multicolumn{3}{c|}{ Control } & \multicolumn{3}{c|}{ Nickel treatment } & \multicolumn{3}{c|}{ Chromium treatment } & \multicolumn{3}{c|}{ Nickel recovery } & \multicolumn{2}{c|}{ Chromium recovery } \\
\hline $2 \theta$ & $D$ & $I$ & $2 \theta$ & $d$ & $I$ & $2 \theta$ & $D$ & $I$ & $2 \theta$ & $d$ & $I$ & $2 \theta$ & $d$ & $I$ \\
\hline 12.843 & 6.915 & 70 & 12.846 & 6.915 & 62 & 12.847 & 6.915 & 68 & 12.842 & 6.915 & 68 & 12.847 & 6.915 & 69 \\
17.249 & 5.185 & 50 & 17.214 & 5.185 & 41 & 17.212 & 5.185 & 45 & 17.218 & 5.185 & 49 & 17.215 & 5.185 & 48 \\
26.656 & 3.351 & 41 & 26.652 & 3.351 & 33 & 26.659 & 3.351 & 37 & 26.658 & 3.351 & 38 & 26.654 & 3.351 & 40 \\
28.266 & 3.164 & 30 & 28.262 & 3.164 & 26 & 28.266 & 3.164 & 29 & 28.260 & 3.164 & 28 & 28.263 & 3.164 & 29 \\
31.713 & 2.823 & 22 & 31.715 & 2.826 & 20 & 31.718 & 2.827 & 20 & 31.714 & 2.825 & 21 & 31.716 & 2.828 & 29 \\
32.801 & 2.730 & 30 & 32.806 & 2.730 & 26 & 32.808 & 2.730 & 28 & 32.805 & 2.730 & 27 & 32.804 & 2.730 & 21 \\
34.975 & 2.570 & 27 & 34.972 & 2.570 & 20 & 34.977 & 2.570 & 25 & 34.972 & 2.570 & 25 & 34.976 & 2.570 & 25 \\
41.612 & 2.170 & 20 & - & - & - & - & - & - & - & - & - & - & - & - \\
45.105 & 2.010 & 16 & - & - & - & - & - & - & - & - & - & - & - & - \\
53.938 & 1.700 & 15 & 53.936 & 1.700 & 10 & 53.932 & 1.700 & 14 & 53.937 & 1.700 & 12 & 53.935 & 1.700 & 13 \\
56.467 & 1.631 & 14 & 56.462 & 1.631 & 11 & 56.468 & 1.631 & 12 & 56.464 & 1.631 & 13 & 56.464 & 1.631 & 13 \\
57.416 & 1.605 & 20 & 56.410 & 1.605 & 14 & 57.415 & 1.605 & 17 & 57.412 & 1.605 & 19 & 57.414 & 1.605 & 18
\end{tabular}

FTIR frequency assignment for bone tissues of control, $\mathrm{Ni}$ and $\mathrm{Cr}$ treated and their recovery tissues. TABLE II

\begin{tabular}{c|c|c|c|c|l}
\hline \hline \multicolumn{5}{c|}{ Wave number $\left[\mathrm{cm}^{-1}\right]$} & \multirow{2}{*}{ Frequency assignment } \\
\cline { 1 - 4 } Control & $\begin{array}{c}\text { Nickel } \\
\text { treated }\end{array}$ & $\begin{array}{c}\text { Chromium } \\
\text { treated }\end{array}$ & $\begin{array}{c}\text { Nickel } \\
\text { recovery }\end{array}$ & $\begin{array}{c}\text { Chromium } \\
\text { recovery }\end{array}$ & \\
\hline $3298(\mathrm{~m})$ & $3299(\mathrm{w})$ & $3301(\mathrm{~m})$ & $3301(\mathrm{~m})$ & $3302(\mathrm{w})$ & O-H stretching/N-H stretching \\
$2925(\mathrm{~m})$ & $2924(\mathrm{w})$ & $2925(\mathrm{~m})$ & $2925(\mathrm{~m})$ & $2925(\mathrm{w})$ & carbonate stretching \\
$1658[\mathrm{~s}]$ & $1658(\mathrm{w})$ & $1658(\mathrm{~m})$ & $1658(\mathrm{w})$ & $1656(\mathrm{w})$ & in plane C=O structure (amide I) \\
$1546(\mathrm{~m})$ & $1546(\mathrm{w})$ & $1547(\mathrm{~m})$ & $1545(\mathrm{w})$ & $1547(\mathrm{w})$ & C-N stretching/N-H bending (amide II) \\
$1240(\mathrm{w})$ & $1239(\mathrm{w})$ & $1240(\mathrm{w})$ & $1238(\mathrm{w})$ & $1239(\mathrm{w})$ & POH deformation \\
$1082(\mathrm{~m})$ & $1081(\mathrm{w})$ & $1082(\mathrm{~m})$ & $1082(\mathrm{~m})$ & $1081(\mathrm{w})$ & carbonate stretching \\
$873(\mathrm{w})$ & $873(\mathrm{w})$ & $872(\mathrm{w})$ & $873(\mathrm{w})$ & $871(\mathrm{w})$ & carbonate stretching \\
$559(\mathrm{w})$ & $560(\mathrm{w})$ & $560(\mathrm{w})$ & $560(\mathrm{w})$ & $561(\mathrm{w})$ & PO $_{4}$ bending \\
\hline
\end{tabular}

$\mathrm{s}$ - strong, $\mathrm{m}$ - medium, w - weak

Concentration of $\mathrm{Ni}, \mathrm{Cr}, \mathrm{Ca}, \mathrm{Mg}$ and $\mathrm{PO}_{4}$ in the bone tissue of Cirrhinus mrigala.

TABLE III

\begin{tabular}{l|c|c|c|c|c|c}
\hline \hline \multicolumn{1}{c|}{ Concentration } & $\begin{array}{c}\mathrm{Ni} \\
{[\mu \mathrm{g} / \mathrm{g}]}\end{array}$ & $\begin{array}{c}\mathrm{Cr} \\
{[\mu \mathrm{g} / \mathrm{g}]}\end{array}$ & $\begin{array}{c}\mathrm{Ca} \\
{[\mathrm{mg} / \mathrm{g}]}\end{array}$ & $\begin{array}{c}\mathrm{Mg} \\
{[\mathrm{mg} / \mathrm{g}]}\end{array}$ & $\begin{array}{c}\mathrm{PO}_{4} \\
{[\mathrm{mg} / \mathrm{g}]}\end{array}$ & $\begin{array}{c}\mathrm{Ca}^{\mathrm{PO}_{4}} \\
\text { ratio }\end{array}$ \\
Treatment & & & & & & \\
\hline control & $8.82 \pm 0.94$ & $21.38 \pm 2.45$ & $172.42 \pm 6.37$ & $5.83 \pm 0.85$ & $86.27 \pm 3.22$ & 1.998 \\
nickel treated & $48.62 \pm 2.53$ & - & $81.64 \pm 5.82$ & $3.94 \pm 0.98$ & $30.43 \pm 3.73$ & 2.683 \\
nickel recovery & $16.64 \pm 1.94$ & - & $124.35 \pm 8.45$ & $4.85 \pm 1.09$ & $44.36 \pm 7.16$ & 2.803 \\
chromium treated & - & $35.37 \pm 3.57$ & $110.27 \pm 9.61$ & $5.13 \pm 0.94$ & $48.85 \pm 7.62$ & 2.257 \\
chromium recovery & - & $30.82 \pm 4.26$ & $104.54 \pm 8.32$ & $5.06 \pm 0.38$ & $42.26 \pm 5.24$ & 2.474 \\
\hline
\end{tabular}

$N=3 \pm$ S.D.

\subsection{FTIR studies}

Figure 2 shows the FTIR spectra of control, nickel and chromium treated bone tissues along with their corresponding recovery tissues. As seen from the figures, the spectra consist of several vibrations of protein components and the inorganic mineral phase of the bone. The overall spectral profile is similar in both except the variation in intensities due to carbonate, phosphate and amide group bands. The decreases in the intensities of the above bands were more pronounced in nickel treatment than in chromium treatment. The possible fre- quency assignments have been reported in Table II. We have mainly assigned $\mathrm{OH}, \mathrm{PO}_{4}$ and carbonate group frequencies and amide bands, which are in agreement with previous FTIR studies [4]. In the present investigation, the broad bands observed at $\approx 3298 \mathrm{~cm}^{-1}$ are assigned as the $\mathrm{OH}$ stretching mode. The bands at $\approx 2925 \mathrm{~cm}^{-1}$, $\approx 1082 \mathrm{~cm}^{-1}$, and $\approx 873 \mathrm{~cm}^{-1}$ were assigned as carbonate bands. The bands observed at $\approx 1240 \mathrm{~cm}^{-1}$ and $\approx 559 \mathrm{~cm}^{-1}$ are due to the $\mathrm{P}_{\mathrm{OH}}$ deformation and $\mathrm{PO}_{4}$ bending modes, respectively. Also, the sharp bands observed at $\approx 1658 \mathrm{~cm}^{-1}$ and $\approx 1546 \mathrm{~cm}^{-1}$ are assigned to the in-plane $\mathrm{C}=\mathrm{O}$ stretching vibration (amide $\mathrm{I}$ ) and 
$\mathrm{C}-\mathrm{N}$ stretching/ $\mathrm{N}-\mathrm{H}$ bending vibration (amide $\mathrm{II}$ ) of tissue proteins, respectively.

For quantitative analysis, the ratio of the peak intensity of each band of the experimental group (treated/recovery) with respect to control/treated group can be used to differentiate normal tissues from the metal treated ones. In the present work the intensity of the carbonate band $\left(\approx 2925 \mathrm{~cm}^{-1}\right.$ ) and $\mathrm{PO}_{4}$ bending band $\left(\approx 559 \mathrm{~cm}^{-1}\right)$ decreases by $45 \%$ and $57 \%$ for nickel treatment and by $25 \%$ and $13 \%$, respectively, for chromium treatment. Also during the period of recovery there is gain in the intensity of carbonate and phosphate bands by $27 \%$ and $45 \%$, respectively, for nickel treatment.

On the other hand, during chromium recovery, the intensity of the above bands decreases further by $46 \%$ and $42 \%$, respectively. From the above observation, one can conclude that the mineral contents are decreased due to $\mathrm{Ni}$ and $\mathrm{Cr}$ treatments. During nickel recovery period, the mineral contents increased, but during chromium recovery period, there is a decline in the mineral content. Similar results have been observed by Larsson et al. [11].

The concentration of $\mathrm{Ni}, \mathrm{Cr}, \mathrm{Ca}, \mathrm{Mg}$ and phosphate as $\mathrm{PO}_{4}$ present in the bone tissues of Cirrhinus mrigala were estimated using ICP-AES and are presented in Table III. It could be observed from the table that bone tissues of fish belonging to the control group contain $8.82 \mu \mathrm{g} / \mathrm{g}, 21.38 \mu \mathrm{g} / \mathrm{g}, 172.42 \mathrm{mg} / \mathrm{g}, 5.83 \mathrm{mg} / \mathrm{g}$ and $86.27 \mathrm{mg} / \mathrm{g}$ of nickel, chromium, calcium, magnesium and phosphate, respectively. But, in the nickel treated bone tissues, the nickel content increased drastically (45\%) to $48.62 \mu \mathrm{g} / \mathrm{g}$ and calcium, magnesium and phosphate contents also decreased drastically $(53 \%, 32 \%$ and $65 \%$, respectively). On the other hand, in bone tissues belonging to the recovery group, nickel content decreased to $16.64 \mu \mathrm{g} / \mathrm{g}$, a decrease of $66 \%$ and $\mathrm{Ca}, \mathrm{Mg}$ and $\mathrm{PO}_{4}$ contents improved significantly $(52 \%, 23 \%$, and $46 \%$, respectively). On the other hand, in chromium treated bone tissues, chromium increased to $35.37 \mu \mathrm{g} / \mathrm{g}$, an increase of $65 \%$ and $\mathrm{Ca}, \mathrm{Mg}$ and $\mathrm{PO}_{4}$ contents also decreased significantly $(36 \%, 12 \%$, and $45 \%$, respectively). But in the recovery group tissues, chromium content is decreased to $30.82 \mu \mathrm{g} / \mathrm{g}$, a decrease of $13 \%$, but there was no improvement in the minerals content, instead the minerals decrease further by $5 \%, 1.3 \%$ and $14 \%$, respectively.

The above observation shows that the treatment of metals, nickel and chromium increases the content of respective metal in bone tissues at the expense of other minerals. These findings are in agreement with those reported by Muramoto [12] in rat bone tissues. The major differences between the control and treated tissue is in the $\mathrm{Ca}: \mathrm{PO}_{4}$ ratio. The increased $\mathrm{Ca}: \mathrm{PO}_{4}$ ratio in the metal treated bone tissue reflects increased mineralisation. Also, it was observed that in the chromium recovery samples, though the chromium content increased, the $\mathrm{Ca}, \mathrm{Mg}$ and $\mathrm{PO}_{4}$ contents did not increase. This may be due to the binding of chromium in bone tissues as evidenced by the presence of higher level of chromium than in the control even after the recovery period. This present ICP-AES study supports the observation that increased $\mathrm{Ca}: \mathrm{PO}_{4}$ ratio in treated samples is attributed to decrease in the $\mathrm{PO}_{4}$ content which can be attributed to the fact that calcium is substituted for $\mathrm{PO}_{4}$ groups which induces atomic misalignment leading to poor crystallization of the bone. Thus structural distortion is an important feature of bone as indicated by X-ray studies suggesting the amorphous nature of the sample. Also during the period of nickel recovery there is an increase in calcium and phosphate, which may be taken from the blood and from other parts of the body. But in the case of chromium treatment there is no gain in calcium, magnesium and phosphate which may be due to the slow elimination of chromium from bone tissues even after recovery $(30.8 \mu \mathrm{g} / \mathrm{g})$. Thus the effect of heavy metals, nickel and chromium results in the lowering of bone mineral contents and our results are in agreement with those of the earlier findings of researchers as Muramota [12], Jagadeesan [13], Kent [14], and Larsson and Haux [15] who have studied the effect of heavy metals on calcium and phosphate metabolism in vertebrates. The present study also indicates that nickel is more toxic than chromium and this observation is in agreement with the FTIR study on muscle protein.

\section{Summary}

The toxic effect of nickel and chromium on bone tissues of an edible fish was studied using XRD and FTIR. The results shows that the toxic effect was more pronounced in nickel than chromium and it was supported from ICPAES study.

\section{References}

[1] S.V. Rama Rao, V.P. Singh, L.D. Mall, in: Glimpses of Ecology, Eds. B. Gopal, J.S. Sing, International Scientific Publications, India 1998, p. 167.

[2] R. Capelli, V. Minganti, Sci. Total Environ. 63, 83 (1987).

[3] H. Babich, C. Shopsis, E. Borenfreund, Bull. Environ. Contam. Toxicol. 37, 550 (1986).

[4] B. Turan, S. Bayani, E. Baleick, Feride Severcan, N. Akkas, Bio Metals 13, 113 (2000).

[5] D.W. Hawker, D.W. Connell, Ecotoxicol. Environ. Saf. 11, 184 (1986).

[6] S. Karthikeyan, P.L.R.M. Palaniappan, S. Sahbanayakam, Int. J. Environ. Prot. 25, 629 (2005).

[7] P.L.R.M. Palaniappan, S. Karthikeyan, J. Environ. Sci. 21, 229 (2009).

[8] S. Karthikeyan, P.L.R.M. Palaniappan, S. Sahbanayakam, Asian J. Chem. 19, 1329 (2007).

[9] S. Karthikeyan, P.L.R.M. Palaniappan, S. Sahbanayakam, J. Environ. Bio. 28, 489 (2007).

[10] G. Topping, Aquaculture 1, 379 (1973).

[11] A. Larrson, B.E. Bengtsson, C. Howsa, Aquat. Toxicol. 1, 19 (1981).

[12] S. Muramoto, Bull. Environ. Contam. 27, 193 (1981).

[13] G. Jagadeesan, Ph.D. Thesis, Annamalai University, 1994.

[14] G.C. Kent, in: Comparative Anatomy of the Vertebrates, Ed. G. Kent, Mosby, Topan, Tokyo 1978, p. 63.

[15] A. Larsson, C. Haux, J. Environ. Biol. 3, 71 (1982). 